(c) American Dairy Science Association, 2003.

\title{
The Effect of Corn Silage Particle Size and Cottonseed Hulls on Cows in Early Lactation
}

\author{
P. J. Kononoff ${ }^{1}$ and A. J. Heinrichs \\ The Pennsylvania State University \\ Department of Dairy and Animal Science, \\ University Park, PA 16802
}

\section{ABSTRACT}

The objective of this study was to evaluate the effects of reducing forage particle length (FPL) and the inclusion of cottonseed hulls (CSH) on intake, digestibility, chewing activity, and milk production of cows in early lactation. Sixteen multiparous cows averaging $17 \pm 3$ $\mathrm{d}$ in milk and $677 \pm 58 \mathrm{~kg} \mathrm{BW}$ were assigned to one of four $4 \times 4$ Latin squares. One square contained ruminally cannulated cows to evaluate effects of treatment on rumen fermentation and function. During each of the 23-d periods, cows were offered one of four total mixed rations that differed in particle length (long or short corn silage) and $\mathrm{CSH}$ inclusion rate (0 or $8 \% \mathrm{DM})$. Dietary treatments were: long no CSH (LGNH), long with CSH (LGH), short no CSH (SHNH), and short with $\mathrm{CSH}$ (SHH). Total physically effective NDF content, measured as percentage of NDF greater than $1.18 \mathrm{~mm}$, was similar across diets, but mean particle length decreased with reducing FPL and inclusion of CSH. Dry matter intake was not significantly affected by FPL but was significantly increased with the inclusion of CSH. Decreasing FPL and the inclusion of CSH significantly increased neutral detergent fiber intake. Total chewing activity expressed as minutes per day was unaffected by FPL and the inclusion of $\mathrm{CSH}$. Both eating and ruminating efficiency expressed as minutes per kilogram of neutral detergent fiber intake increased with increasing FPL and decreased with the inclusion of CSH. Milk production did not differ across treatments, but the inclusion of CSH significantly increased percent and yield of milk protein. Reducing FPL tended to reduce percentage milk fat but not yield. Mean ruminal $\mathrm{pH}$ was not affected by FPL but was highest on diets containing CSH, even though no treatment effects were observed on total VFA, acetate, or propionate concentration. These re-

Received July 12, 2002.

Accepted November 1, 2002.

Corresponding author: A. J. Heinrichs; e-mail: ajh@psu.edu.

${ }^{1}$ Current address: Renaissance Nutrition, Inc. P.O. Box \#229, 481 Frederick Road, Roaring Spring, PA 16673. sults indicate that corn silage FPL is a poor predictor of total chewing time and rumen $\mathrm{pH}$ but is useful in understanding factors affecting feeding behavior. In addition, the inclusion of $\mathrm{CSH}$, resulted in increased rumination and mean rumen $\mathrm{pH}$ even though effects on VFA concentration were not observed.

(Key words: forage particle length, rumination, and cottonseed hulls)

Abbreviation key: CSH = cottonseed hulls, FPL = forage particle length, LG = long, $\mathbf{L G H}=$ long corn silage with cottonseed hulls, LGNH = long corn silage with no cottonseed hulls, NDFI = neutral detergent fiber intake, NFFS = nonforage fiber sources, peNDF $=$ physically effective neutral detergent fiber, PSPS = Penn State Particle Separator, $\mathbf{S H}=$ short, $\mathbf{S H H}=$ short corn silage with with cottonseed hulls, $\mathbf{S H N H}=$ short corn silage with no cottonseed hulls, $\mathbf{T C}=$ total chewing activity, $\mathbf{T N C}=$ total nonstructural carbohydrate, $\mathbf{X}_{\mathbf{g m}}=$ geometric mean length.

\section{INTRODUCTION}

Current NRC (2001) requirements outline that maximum ration NDF is a function of the nonfiber carbohydrate concentration, its effect on intake, and the cow's $\mathrm{NE}_{\mathrm{L}}$ requirement. In comparison, minimum NDF required is constrained by the ration's ability to maintain proper rumen function and fermentation. Ration particle size has been observed to affect DMI, chewing activities, and rumen fermentation and is linked to the ability of the ration to meet the animal's fiber requirement (NRC, 2001). The concept of effective fiber was created to amalgamate the chemical and physical nature of the forage and to quantify its value to rumen function. Physically effective NDF (peNDF) is defined as that dietary fiber source, which effectively stimulates rumination and salivation (Mertens, 1997). Poppi et al. (1985) determined that particles that were retained on a sieve measuring $1.18 \mathrm{~mm}$ pass out of the rumen slower than those that are not retained. Mertens (1997) suggested that in order for particles $>1.18$ $\mathrm{mm}$ to pass out of the rumen they would have to be reduced through comminution, and as a result, these 
particles would stimulate more saliva secretion than those $<1.18 \mathrm{~mm}$.

In the northeastern United States, corn silage is commonly used as a major forage component of dairy rations. The high nutritional value of corn silage is in part due to its relatively high palatability and energy value; in addition, the corn silage contributes to the animal fiber requirement. Similar to other forages, the value of corn silage may be greatly influenced by harvesting techniques. Fine chopping corn silage improves packing density and fermentation, but its effect on the chewing activity and rumen fermentation is less clear. Although reduction in forage particle size usually results in reduced chewing activity (De Boever et al., 1993), the effects on DMI and digestion have remained less clear. Positive effects on DMI with reduced particle size have been reported in some studies (Weigand et al., 1993; Stockdale and Beavis, 1994) but have not been observed in others (Schwab et al., 2002). In contrast, total-tract NDF digestibility has been observed to increase with increasing chop length (Bal et al., 2000), and as a result, interactive effects between fiber digestion and chop length may exist.

Nonforage fiber sources (NFFS) possess inherently different physical and chemical properties as compared to forages, ultimately affecting the nature of the associated NDF. When compared to forage, NFFS have a smaller particle size and higher specific gravity resulting in shorter rumen retention time and lower digestibility and organic acid production (Allen and Grant, 2000). Cottonseed hulls (CSH) are a by-product of cotton processing, contain a large proportion of NDF and associated lignin, and have been considered a useful NFFS when forage stores are limiting (Hall and Akinyode, 2000). As a result of the fine particle size and fiber value, inclusion of cottonseed hulls in ruminant diets have increased DMI (Van Horn et al., 1984), resulted in higher rumen $\mathrm{pH}$ (Hsu et al., 1987), and decreased nutrient digestibility in total tract of $\mathrm{DM}$ and NDF (Akinyode et al., 1999). However, studies examining the inclusion of CSH into corn silage-based diets and effects on milk production is limited. Because forages provide NDF in a form that is distinctively different than NFFS, experiments designed to delineate the effects of NDF source must continue.

If guidelines outlining the physical requirements of feed are to be established, an empirical, repeatable, and accurate system to analyze feed particle size must be developed and universally accepted. Based on properties of the ASAE Standard (S424) of forage particle size determination, the Penn State Particle Separator (PSPS) is a quick and cost-effective method of TMR particle size analysis (Lammers et al., 1996). The manually operated PSPS has three screens and a bottom pan. The two round-hole sieves have diameters of 19.0 and $8.0 \mathrm{~mm}$ and have a thickness of 12.2 and $6.4 \mathrm{~mm}$. The third metal, square-meshed sieve with a nominal size opening of $1.18 \mathrm{~mm}$ has recently been added to the device (Kononoff et al., 2003). The additional screen further partitions the smaller particle fraction, which is less than $8.0 \mathrm{~mm}$. The addition of the sieve measuring $1.18 \mathrm{~mm}$ now allows the user of the PSPS to estimate that portion of the diet, which has been described to rapidly pass out of the rumen and is believed to be useful in estimating peNDF (Poppi et al., 1985; Mertens, 1997).

The objectives of the following experiment were 1) to determine the effects of feeding corn silage-based diets of different particle size to cows in early lactation and 2) to evaluate the ability of the PSPS to measure effective fiber.

\section{MATERIALS AND METHODS}

\section{Diets, Cows, and Experimental Design}

Pioneer corn hybrid 34K77 (Pioneer Hi-Bred International, Des Moines, IA) was harvested at a whole plant DM content of $30.6 \pm 1.9 \%$. Corn was harvested using a self-propelled forage harvester (John Deere, model 6750) set at $22.3 \mathrm{~mm}$ theoretical length of cut. The chopped material was then placed in a concrete bunker, covered with black plastic, ensiled for approximately $100 \mathrm{~d}$ and designated "long" forage. Every second day during the course of the experiment, silage was rechopped using a pull type forage harvester (New Holland, model 900) set at $4.8 \mathrm{~mm}$ theoretical length of cut, stored at $4{ }^{\circ} \mathrm{C}$, and designated "short" forage. Tables 1 and 2 include nutrient composition and particle size measurements of the corn silage used in the experimental diets.

During each of the 23-d periods, cows were offered one of four TMR that differed in FPL (long (LG) or short (SH) corn silage) or CSH inclusion rate (0 or $8 \%$ DM). Dietary treatments were 1) long corn silage no CSH (LGNH), 2) long corn silage with CSH (LGH), 3) short corn silage no CSH (SHNH), and 4) short corn silage with CSH (SHH). Each diet was formulated to be chemically identical but different in corn silage particle length and cottonseed hull inclusion rate (Tables 3 and 4). All diets were mixed separately using a small drum mixer (Data Ranger; American Calan, Inc., Northwood, NH).

Sixteen lactating multiparous Holstein cows averaging $17 \pm 3$ DIM and weighing $677 \pm 58 \mathrm{~kg}$ were randomly assigned to one of four $4 \times 4$ Latin squares (using a $2 \times 2$ factorial arrangement of treatments). One square included ruminally cannulated cows and was used for all rumen and chewing measurements, while 
Table 1. Corn silage chemical composition and fermentation measures.

\begin{tabular}{lcl}
\hline & Mean & SEM \\
\hline DM & 30.6 & 1.09 \\
CP, \% DM & 9.3 & 0.40 \\
Soluble protein, \% DM & 5.1 & 0.06 \\
Ether extract, \% DM & 2.8 & 0.11 \\
NDF, \% DM & 39.6 & 1.21 \\
NDIN, \% DM & 1.4 & 0.12 \\
ADF, \% DM & 22.4 & 0.75 \\
Lignin, \% DM & 3.1 & 0.03 \\
TNC, \% DM 1 & 34.9 & 1.62 \\
NFC, \% DM & & 1.56 \\
Ca, \% DM & 46.2 & 0.03 \\
P,\% DM & 0.3 & 0.02 \\
Mg, \% DM & 0.3 & 0.01 \\
K, \% DM & 0.2 & 0.11 \\
pH & 1.2 & 0.1 \\
Ammonia & 3.7 & 0.06 \\
Lactic acid, \% DM & 0.5 & 0.7 \\
Acetic acid, \% DM & 5.1 & 0.4 \\
Butyric acid, \% DM & 0.5 & $\ldots$ \\
Propionic acid, \% DM & $<0.01$ & $\ldots$ \\
Isobutyric acid, \% DM & $<0.01$ & $\ldots$ \\
\hline
\end{tabular}

${ }^{1} \mathrm{TNC}=$ Total nonstructural carbohydrates (Smith, 1981).

${ }^{2} \mathrm{NFC}=$ Nonfiber carbohydrate calculated by difference $100-(\%$ $\mathrm{NDF}+\% \mathrm{CP}+\% \mathrm{Fat}+\% \mathrm{ASH})$.

all squares were used for production and intake data. Cows were housed in individual stalls and milked at 0730 and $1930 \mathrm{~h}$. Cows were fed at $0800 \mathrm{~h}$ for ad libitum consumption to allow for approximately $5 \%$ refusal. The experimental cows were cared for according to the guidelines stipulated by the Pennsylvania State University Animal Care and Use Committee.

\section{Experimental Measures and Sample Analysis Feed and Ort Analysis}

Samples of feed were collected daily and composited weekly. Collected samples were immediately frozen $\left(-20^{\circ} \mathrm{C}\right)$ and stored for further analysis. Samples were

Table 2. Particle size distribution and geometric mean length for long and short corn silage as measured by the Penn State Particle Separator.

\begin{tabular}{|c|c|c|c|}
\hline & LONG & SHORT & SEM \\
\hline \multirow{2}{*}{\multicolumn{2}{|c|}{$-(\%$ DIV retained $)-$}} & ined) & \\
\hline & & & \\
\hline$>19.0 \mathrm{~mm}$ & 25.9 & 6.8 & 1.0 \\
\hline $19.0-8.0 \mathrm{~mm}$ & 59.3 & 65.2 & 0.9 \\
\hline $8.0-1.18 \mathrm{~mm}$ & 14.2 & 27.1 & 0.5 \\
\hline$<1.18 \mathrm{~mm}$ & 0.6 & 0.9 & 0.1 \\
\hline $\mathrm{X}_{\mathrm{gm}},{ }^{1} \mathrm{~mm}$ & 12.9 & 9.2 & 0.2 \\
\hline $\mathrm{S}_{\mathrm{gm}},{ }^{2} \mathrm{~mm}$ & 1.96 & 1.93 & 0.02 \\
\hline
\end{tabular}

then dried at $55^{\circ} \mathrm{C}$ in a forced-air oven and ground (1mm screen; Wiley mill, Aurthur A. Thomas Co., Philadelphia, PA). All feed and forage samples were analyzed in duplicate for moisture, Kjeldahl nitrogen using a Kjetec 1030 autoanalyzer, ether extract, calcium and phosphorus and percent ash (AOAC, 1990). NDF (Van Soest et al., 1991), ADF, and acid detergent lignin (AOAC, 1990) were analyzed according to the procedure of Van Soest et al. (1991). Neutral detergent insoluble nitrogen and ADIN were analyzed on NDF and ADF residues (AOAC, 1990). Heat stable alpha-amylase (number A3306; Sigma Chemical Co., St. Louis, MO) was included in the NDF procedure (100 $\mu \mathrm{L}$ per $0.50 \mathrm{~g}$ of sample). Total nonstructural carbohydrate (TNC) was determined according to the procedure of Smith (1981) but modified to use ferricyanide as a colorimetric indicator. All ort samples were analyzed in duplicate for $\mathrm{ADF}$, ash, $\mathrm{CP}$, ether extract, moisture, $\mathrm{NDF}$, and NSC.

\section{Chewing Activity}

Eating and ruminating activity was measured during $\mathrm{d} 15$ and 16 of each period using Graze Jaw Movement Analysis Software of the IGER Behavior Recorder (Ultra Sound Advice, London, UK) described by Rutter et al. (1997). On d 15 and 16 ort samples were collected and analyzed separately to calculate DM and NDF intake on days in which chewing activities were measured. Data were expressed as daily eating, ruminating, or total chewing activity (TC) by calculating the sum of eating and ruminating time over a 24-h period. Activities per unit of DM and NDF intake were also calculated by dividing total minutes or number of bites by the mean of each parameter measured.

\section{Apparent Digestibility Markers}

Beginning on d 9 of each period at 0800 and 2000 $\mathrm{h}$, one capsule containing $5 \mathrm{~g}$ of $\mathrm{Cr}_{2} \mathrm{O}_{3}$ was placed in the dorsal area of the rumen via the cannula for measurements of apparent total-tract digestibility. Beginning on d 17, approximately $250 \mathrm{~g}$ of fecal material was collected at $0,6,12,18,24,25,32,38.543,50$, $52,58,70,76,78,84,90,96,102$, and $118 \mathrm{~h}$ and stored at $-20^{\circ} \mathrm{C}$. Samples were then dried at $55^{\circ} \mathrm{C}$ in a forced air oven ground (1-mm screen; Wiley mill, Aurthur A. Thomas Co., Philadelphia, PA) and composited by cow and period. All fecal samples were analyzed in duplicate for moisture, ash, CP, NDF, ADF, TNC, EE, and nonfiber carbohydrate. Whole diet TDN concentration was determined using apparent digestibility of $\mathrm{CP}$, $\mathrm{EE}$, nonfiber carbohydrate, and NDF components of the whole diet (Weiss et al., 1992). Based on these 
TMR PARTICLE SIZE AND DAIRY CATTLE

Table 3. Ingredient and chemical composition of total mixed diets (DM basis).

\begin{tabular}{|c|c|c|c|c|c|}
\hline & \multicolumn{4}{|c|}{ Treatment $^{1}$} & \multirow[b]{2}{*}{ SEM } \\
\hline & LGNH & LGH & SHNH & $\mathrm{SHH}$ & \\
\hline \multicolumn{6}{|l|}{ Diet ingredients } \\
\hline Corn silage & 57.4 & 45.8 & 57.4 & 45.8 & $\ldots$ \\
\hline Cottonseed hulls & 0.0 & 7.8 & 0.0 & 7.8 & $\ldots$ \\
\hline Ground corn & 11.2 & 17.2 & 11.2 & 17.2 & $\ldots$ \\
\hline Soybeans & 6.1 & 10.4 & 6.1 & 10.4 & $\ldots$ \\
\hline Distillers grain & 6.9 & 0.9 & 6.9 & 0.9 & $\ldots$ \\
\hline Wheat middlings & 6.9 & 6.0 & 6.9 & 6.0 & $\ldots$ \\
\hline Soybean meal & 6.7 & 7.9 & 6.7 & 7.9 & $\ldots$ \\
\hline Blood meal & 0.6 & 0.3 & 0.6 & 0.3 & $\ldots$ \\
\hline Feather meal & 0.6 & 0.3 & 0.6 & 0.3 & $\ldots$ \\
\hline Fish meal & 0.6 & 0.3 & 0.6 & 0.3 & $\ldots$ \\
\hline Salt & 0.50 & 0.49 & 0.50 & 0.49 & $\ldots$ \\
\hline Magnesium oxide & 0.35 & 0.34 & 0.35 & 0.34 & $\ldots$ \\
\hline Limestone & 1.48 & 1.58 & 1.48 & 1.58 & $\ldots$ \\
\hline Calcium sulfate & 0.25 & 0.25 & 0.25 & 0.25 & $\ldots$ \\
\hline Trace mineral $\operatorname{mix}^{2}$ & 0.02 & 0.03 & 0.02 & 0.03 & $\ldots$ \\
\hline Urea & 0.35 & 0.42 & 0.35 & 0.42 & $\ldots$ \\
\hline Vitamin $\mathrm{ADE}^{3}$ & 0.02 & 0.02 & 0.02 & 0.02 & $\ldots$ \\
\hline \multicolumn{6}{|l|}{ Chemical } \\
\hline Moisture & 55.3 & 50.3 & 56.9 & 51.4 & 0.55 \\
\hline $\mathrm{CP}$ & 18.4 & 17.7 & 18.0 & 19.2 & 0.36 \\
\hline Soluble CP & 5.7 & 4.9 & 5.7 & 5.3 & 0.31 \\
\hline $\mathrm{TNC}^{4}$ & 33.0 & 33.9 & 35.6 & 34.0 & 0.50 \\
\hline NDF & 29.1 & 31.5 & 29.9 & 32.3 & 0.35 \\
\hline $\mathrm{ADF}$ & 20.3 & 22.1 & 21.1 & 21.6 & 0.38 \\
\hline Ether extract & 5.1 & 5.1 & 4.7 & 4.6 & 0.06 \\
\hline $\mathrm{NFC}^{5}$ & 39.0 & 38.2 & 38.2 & 37.9 & 0.51 \\
\hline Ash & 6.9 & 6.5 & 6.9 & 6.6 & 0.11 \\
\hline $\mathrm{Ca}$ & 0.96 & 0.97 & 0.94 & 0.92 & 0.03 \\
\hline $\mathrm{Mg}$ & 0.38 & 0.34 & 0.39 & 0.37 & 0.01 \\
\hline $\mathrm{P}$ & 0.43 & 0.39 & 0.44 & 0.40 & $<0.01$ \\
\hline $\mathrm{K}$ & 1.5 & 1.6 & 1.2 & 1.3 & 0.03 \\
\hline
\end{tabular}

${ }^{1} \mathrm{LGNH}=\mathrm{TMR}$ with long corn silage, no cottonseed hulls, LGH = TMR with long corn silage and cottonseed hulls, SHNH = TMR with short corn silage and no cottonseed hulls, and SHH = TMR with short corn silage with cottonseed hulls.

${ }^{2}$ Contained $0.57 \%$ calcium, $1362.2 \mathrm{mg} / \mathrm{kg}$ cobalt, 40,816.3 mg/kg copper, $2,724.5 \mathrm{mg} / \mathrm{kg}$ iodine, 10,204.1 $\mathrm{mg} / \mathrm{kg}$ iron, $1222,449.0 \mathrm{mg} / \mathrm{kg}$ manganese, $15.8 \%$ sulfur, $12,2450.0 \mathrm{mg} / \mathrm{kg}$ zinc.

${ }^{3}$ Contained 28,792.5 KIU/kg vitamin A, 7,198.5 KIU/kg vitamin D, 179,959.6 IU/kg vitamin E.

${ }^{4} \mathrm{TNC}=$ Total nonstructural carbohydrates (Smith, 1981).

${ }^{5} \mathrm{NFC}=$ Nonfiber carbohydrate calculated by difference $100-(\% \mathrm{NDF}+\% \mathrm{CP}+\%$ Fat $+\% \mathrm{ASH})$.

values, production levels of digestible energy, metabolizable energy, and $\mathrm{NE}_{\mathrm{L}}$ were calculated as outlined by NRC (2001).

\section{Ruminal Sampling and Emptying}

Liquid passage rates were determined using CoEDTA as described by Lykos et al. (1997). For measurements of liquid passage animals were given a pulse dose of Co $(10 \mathrm{~g}$ of Co-EDTA dissolved in $1 \mathrm{~L}$ of tap water) prior to the a.m. feeding on $\mathrm{d} 17$ of each period. Liquid passage rates were then calculated according to the description of Grovum and Williams (1973). On d 17 of each period ruminal contents were collected from the dorsal, ventral, and caudal area in the rumen at $0.0,1.5,3.5,5.5,8.5,11.5,14.5,18,21.5$, and $24.5 \mathrm{~h}$, prior to beginning Co dosing $(0.0 \mathrm{~h})$. Col- lected digesta were mixed and filtered through four layers of cheesecloth. Rumen liquid $\mathrm{pH}$ determination was immediately determined by using a hand-held $\mathrm{pH}$ electrode (model M90, Corning Inc., Corning, NY). Approximately, $15 \mathrm{ml}$ of filtered liquid was then placed into bottles containing $3 \mathrm{ml}$ of $25 \%$ metaphosphoric acid and $3 \mathrm{ml}$ of $0.6 \%$ 2-ethly butyric acid (internal standard) and stored at $-20^{\circ} \mathrm{C}$. Samples were later centrifuged three times at $4000 \times g$ for $30 \mathrm{~min}$ at $4^{\circ} \mathrm{C}$ to obtain a clear supernatant that was analyzed for ammonia using a phenol-hypochlorite assay (Broderick and Kang, 1980; Lykos et al., 1997) and VFA concentration using gas chromatography (Yang and Varga, 1989). In addition, $50 \mathrm{ml}$ of rumen liquid was collected for Co analysis using the procedure described by Hart and Polan (1984) (atomic absorption; Instru- 
Table 4. Effects of forage particle length (FPL) and fiber source (FS) on particle size distribution, NDF content, and physically effective neutral detergent fiber (peNDF) values for experimental diets.

\begin{tabular}{|c|c|c|c|c|c|c|c|c|}
\hline & \multicolumn{4}{|c|}{ Treatment $^{1}$} & \multirow[b]{2}{*}{ SEM } & \multicolumn{3}{|c|}{ Contrast } \\
\hline & LGNH & LGH & SHNH & $\mathrm{SHH}$ & & FPL & FS & $\mathrm{I}^{2}$ \\
\hline & & $\% \mathrm{DM}$ & ained & - & & & & \\
\hline \multicolumn{9}{|l|}{ Particle size } \\
\hline$>19.0 \mathrm{~mm}$ & 10.9 & 6.5 & 3.3 & 2.3 & 1.04 & $<0.01$ & 0.03 & 0.13 \\
\hline $19.0-8.0 \mathrm{~mm}$ & 52.3 & 48.2 & 53.0 & 47.9 & 2.26 & 0.92 & 0.07 & 0.83 \\
\hline $8.0-1.18 \mathrm{~mm}$ & 30.4 & 38.1 & 36.5 & 41.3 & 1.36 & $<0.01$ & $<0.01$ & 0.31 \\
\hline$<1.18 \mathrm{~mm}$ & 6.4 & 7.2 & 7.2 & 8.5 & 1.44 & 0.51 & 0.89 & 0.88 \\
\hline $\mathrm{X}_{\mathrm{gm}},{ }^{3} \mathrm{~mm}$ & 7.9 & 6.8 & 6.8 & 6.1 & 0.42 & 0.05 & 0.05 & 0.65 \\
\hline $\mathrm{S}_{\mathrm{gm}},{ }^{4} \mathrm{~mm}$ & 2.5 & 2.4 & 2.3 & 2.4 & 0.10 & 0.31 & 0.91 & 0.60 \\
\hline & Particle Size & - \% & $\mathrm{F}$ & & & & & \\
\hline$>19.0 \mathrm{~mm}$ & 62.7 & 62.0 & 60.9 & 63.5 & 2.28 & 0.92 & 0.65 & 0.43 \\
\hline $19.0-8.0 \mathrm{~mm}$ & 34.6 & 34.6 & 37.8 & 37.8 & 1.04 & $<0.01$ & 0.99 & 0.96 \\
\hline $8.0-1.18 \mathrm{~mm}$ & 21.4 & 30.8 & 27.6 & 27.4 & 1.28 & 0.25 & $<0.01$ & $<0.01$ \\
\hline$<1.18 \mathrm{~mm}$ & 17.1 & 14.6 & 16.4 & 14.0 & 0.74 & 0.39 & $<0.01$ & 0.93 \\
\hline peNDF $^{5}$ & 31.3 & 32.4 & 32.0 & 30.6 & 1.10 & 0.64 & 0.89 & 0.23 \\
\hline
\end{tabular}

${ }^{1} \mathrm{LGNH}=\mathrm{TMR}$ with long corn silage, no cottonseed hulls, $\mathrm{LGH}=\mathrm{TMR}$ with long corn silage and cottonseed hulls, $\mathrm{SHNH}=$ TMR with short corn silage and no cottonseed hulls, and SHH = TMR with short corn silage with cottonseed hulls.

${ }^{2}$ FPL $\times$ FS interaction.

${ }^{3} \mathrm{X}_{\mathrm{gm}}=$ Geometric mean length as calculated by the ASAE (S424), 2001.

${ }^{4} \mathrm{~S}_{\mathrm{gm}}=$ Geometric standard deviation as calculated by ASAE (S424), 2001.

${ }^{5}$ peNDF $=$ Ration NDF multiplied by amount of DM $>1.18 \mathrm{~mm}$.

mentation Laboratories, model 22, aa/ae spectrophotometer, Allied, Analytical Systems, Waltham, MA).

The last day of each period and $4 \mathrm{~h}$ after feeding, approximately $500-\mathrm{ml}$ samples from the dorsal, ventral, and caudal areas in the rumen and fecal samples were collected and weighed for determination of DM, NDF, and particle size. The rumen of each cow was then emptied into large plastic bins and mixed thoroughly. Total digesta amounts were weighed, and three $500-\mathrm{ml}$ samples were collected and frozen at $\left(-20^{\circ} \mathrm{C}\right)$. All remaining digesta were manually repacked into the rumen of each cow.

\section{Particle Size Analysis}

The PSPS was used to measure particle size for both forage and TMR as described by Kononoff et al. (2003). Physically effective NDF was estimated by multiplying the concentration of NDF in the diet by the amount of DM retained on the 19.0-, 8.0-, and 1.18$\mathrm{mm}$ sieves (Mertens, 1997). Particle size of feed digesta and fecal samples were determined using wet-sieving techniques as described by Beauchemin et al. (1997) using an Analysette 3 PRO Vibratory Sieve Shaker (Fritsch, Oberstein, Germany). Approximately $30 \mathrm{~g}$ of wet material was soaked in $1 \mathrm{~L}$ of distilled water for $10 \mathrm{~min}$ and then placed on a series of stacked sieves arranged in descending size and shaken for $10 \mathrm{~min}$. Subsequent to sieving, material was removed from each sieve and dried in a forced air oven at $55^{\circ} \mathrm{C}$ to determine the amount of DM retained on each sieve. Percent of dry matter retained on each sieve, geometric mean $\left(\mathbf{X}_{\mathrm{gm}}\right)$, and standard deviation were calculated as outlined by the ASAE (2001) (S424).

\section{Milk Production}

Milk production was measured and recorded daily from d 15 to 23 of each period. On d 15, 16, 19, and 20 milk samples were collected and preserved using 2-bromo-2-nitropropane-1,3 diol. Milk samples were analyzed for milk fat and true protein by the Pennsylvania DHIA milk testing laboratory using infrared spectrophotometry (Foss 605B Milk-Scan; Foss Electric, Hillerød, Denmark).

\section{Statistical Analyses}

Performance data were analyzed as a replicated 4 $\times 4$ Latin square with model effects for square, period within square, and treatment as fixed effects as well as cow within square as a random effect. Sum of squares for all treatments were then partitioned into single degree of freedom contrasts for forage particle length (FPL), fiber source, and FPL by fiber source interaction planned a priori. The first order autoregressive covariance structure (AR(1)) and the MIXED procedure of SAS (1999) were used to analyze all data. 
Repeated measurements of rumen ammonia, $\mathrm{pH}$, and VFA concentration were analyzed by including a REPEATED model statement, as well as a term for time and interaction for treatment by time. Square by treatment interaction was tested but was not significant and therefore was dropped from the model. Significance for all models was declared at $P \leq 0.05$, and trends are discussed at $P \leq 0.10$. All means presented are least squares means.

\section{RESULTS AND DISCUSSION}

\section{Ration Particle Size and Effective Fiber Measurements}

When measured using the PSPS, particle size distribution and $\mathrm{X}_{\mathrm{gm}}$ reflected the degree of rechopping of corn silage (Table 2) and amount of CSH included in diets (Table 4). The dietary proportion of particles $\geq 19.0 \mathrm{~mm}$ significantly decreased with rechopping and with the inclusion of CSH. Similarly, when diets were composed of either short forage or included $\mathrm{CSH}, \mathrm{X}_{\mathrm{gm}}$ was significantly lower. Most notably, the longest $\mathrm{X}_{\mathrm{gm}}$ was observed on LGNH $(7.9 \mathrm{~mm})$, and the shortest $\mathrm{X}_{\mathrm{gm}}$ was observed on $\mathrm{SHH}(6.1 \mathrm{~mm})$. Even though the amount of particles less than $1.18 \mathrm{~mm}$ was not significantly different across treatments, in diets containing $\mathrm{CSH}$ this fraction contained less NDF. Across treatments peNDF values were not different and averaged 31.6 (Table 4). In a survey evaluating TMR physical form ( $n=831$ samples), Heinrichs et al. (1999) reported that TMR samples fed on commercial dairy farms typically contain 7,35 , and $58 \%$ of the material retained on the 19- and 8-mm sieves, respectively. In the same study a minimum of 1.1 and a maximum of $43.1 \%$ was observed on the 19 -mm sieve, while a minimum of 2.4 and a maximum of $69.1 \%$ was retained on the $8-\mathrm{mm}$ sieve. Based on these results, the range of TMR particle size used in the current study is indicative of those found on commercial dairy farms.

Differences in TMR particle size were small (less than 10\%), but practically, harvesting a longer particle size would create serious deleterious effects, as proper packing density necessary to initiate and sustain proper fermentation, would be more difficult to achieve. Although it is difficult to harvest corn silage much longer, LG corn silage in this experiment was similar to that used by Bal et al. (2000) who reported a long corn silage treatment containing $21.5 \%$ of the material $>18.0 \mathrm{~mm}$. Conversely, based on pretrial evaluations, differences between LG and SH silages were not increased by rechopping the forage more than once. Based on observations, differences between LG and $\mathrm{SH}$ diets were large as virtually no round cob particles were visible in the SH silage, and stover particles were severely reduced in size.

\section{Intake and Body Weight}

Orts adjusted DM and NDF intake and BW are presented in Table 5. Forage particle length did not significantly affect DMI. These results are in contrast to some studies in which positive effects on DMI and NDFI from reduced particle size have been reported (Stockdale and Beavis, 1994; Schwab et al., 2002) but are in agreement with others in which no effect was observed (De Boever et al., 1993; Clark and Armentano, 1999; Bal et al., 2000). The inclusion of $\mathrm{CSH}$ significantly increased DMI and as a result also significantly increased NDFI when expressed as either total amount per day or percentage of body weight. Although particulate rate of passage was not measured, these results support the suggestion that $\mathrm{CSH}$ are of high palatability and that an increased rate of passage will accompany increased intake (Hall and Akinyode, 2000). Furthermore, these results are similar to others who have reported that rations containing NFFS may result in higher levels of DM and NDF fill in the rumen and that the NDF fraction of some NFFS may be less digestible in the rumen than that in forages (Bhatti and Firkins, 1995; Clark and Armentano, 1997).

Both total body weight and body weight change were significantly increased in cows fed SH corn silage, but cows fed diets that included LG corn silage lost body weight. Inclusion of CSH did not affect either total or change in body weight, similar to others (Brown et al., 1977). Because of the short experimental periods and the crossover design of this experiment, we cannot completely attribute gain to the physical makeup of the diets.

\section{Eating and Ruminating Activities}

Decreasing FPL did not affect total eating time per day but significantly increased ruminating time. In comparison TC per kilogram of NDFI tended $(P<0.1)$ to be higher for diets containing LG corn silage (Table 6). Although differences in eating, ruminating, or TC are often not observed when feeding corn silage of different particle size (Clark and Armentano, 1999; Bal et al., 2000), effects observed in the present study are likely to be a result of an increased sorting tendency when LG corn silage was fed. We originally hypothesized that decreasing FPL would decrease total time spent ruminating; the sorting of the long treatment was not anticipated but has been observed by others (Methu et al., 2001). Through visual observa- 
Table 5. Effects of forage particle length (FPL) and fiber source (FS) on body weight, intake, and ort composition on dairy cows in early lactation.

\begin{tabular}{|c|c|c|c|c|c|c|c|c|}
\hline & \multicolumn{4}{|c|}{ Treatment $^{1}$} & \multirow[b]{2}{*}{ SEM } & \multicolumn{3}{|c|}{ Contrast } \\
\hline & LGNH & LGH & SHNH & SHH & & FPL & FS & $\mathrm{I}^{2}$ \\
\hline BW, kg & 676 & 681 & 682 & 686 & 14.9 & 0.03 & 0.11 & 0.76 \\
\hline $\mathrm{BWCH},{ }^{3} \mathrm{~kg} / \mathrm{d}$ & -0.42 & -0.11 & 0.06 & 0.12 & 0.13 & 0.01 & 0.19 & 0.35 \\
\hline DMI, kg/d & 25.69 & 27.60 & 26.1 & 28.31 & 0.56 & 0.22 & $<0.01$ & 0.69 \\
\hline DMI, \%BW & 3.82 & 4.06 & 3.85 & 4.14 & 0.10 & 0.38 & $<0.01$ & 0.62 \\
\hline NDF intake, kg/d & 7.17 & 8.32 & 7.69 & 8.92 & 0.20 & $<0.01$ & $<0.01$ & 0.81 \\
\hline $\mathrm{NDF}$ intake, \% BW & 1.07 & 1.23 & 1.13 & 1.31 & 0.04 & $<0.01$ & $<0.01$ & 0.67 \\
\hline NDF of orts, $\%$ & 48.1 & 44.4 & 35.2 & 35.9 & 1.1 & $<0.01$ & 0.17 & 0.04 \\
\hline
\end{tabular}

${ }^{1} \mathrm{LGNH}=$ TMR with long corn silage, no cottonseed hulls, $\mathrm{LGH}=\mathrm{TMR}$ with long corn silage and cottonseed hulls, $\mathrm{SHNH}=\mathrm{TMR}$ with short corn silage and no cottonseed hulls, and SHH = TMR with short corn silage with cottonseed hulls.

${ }^{2} \mathrm{FPL} \times \mathrm{FS}$ interaction

${ }^{3} \mathrm{BWCH}=$ Body weight change, kg per day.

Table 6. Effects of forage particle length (FPL) and fiber source (FS) on eating, ruminating, and total chewing activity on dairy cows in early lactation.

\begin{tabular}{|c|c|c|c|c|c|c|c|c|}
\hline & \multicolumn{4}{|c|}{ Treatment $^{1}$} & \multirow[b]{2}{*}{ SEM } & \multicolumn{3}{|c|}{ Contrast } \\
\hline & LGNH & LGH & SHNH & $\mathrm{SHH}$ & & FPL & FS & $\mathrm{I}^{2}$ \\
\hline \multicolumn{9}{|l|}{ Bouts/d } \\
\hline Eating & 10.3 & 10.7 & 10.5 & 10.4 & 0.70 & 0.97 & 0.86 & 0.66 \\
\hline Ruminating & 13.8 & 14.5 & 15.5 & 13.8 & 1.6 & 0.65 & 0.63 & 0.32 \\
\hline \multicolumn{9}{|l|}{ Bouts/kg DMI } \\
\hline Eating & 0.41 & 0.39 & 0.41 & 0.38 & 0.03 & 0.89 & 0.47 & 0.93 \\
\hline Ruminating & 0.55 & 0.52 & 0.59 & 0.51 & 0.06 & 0.78 & 0.34 & 0.56 \\
\hline \multicolumn{9}{|c|}{ Bouts/kg NDFI ${ }^{3}$} \\
\hline Eating & 1.48 & 1.28 & 1.36 & 1.17 & 0.11 & 0.29 & 0.12 & 0.95 \\
\hline Ruminating & 2.0 & 1.73 & 1.98 & 1.56 & 0.21 & 0.54 & 0.11 & 0.60 \\
\hline \multicolumn{9}{|l|}{ Min/bout } \\
\hline Eating & 25.1 & 26.1 & 25.2 & 23.3 & 1.8 & 0.44 & 0.62 & 0.36 \\
\hline Ruminating & 36.3 & 34.2 & 32.0 & 35.8 & 3.8 & 0.67 & 0.82 & 0.38 \\
\hline \multicolumn{9}{|l|}{$\operatorname{Min} / \mathrm{d}$} \\
\hline Eating & 264.3 & 263.0 & 252.2 & 257.1 & 28.1 & 0.64 & 0.92 & 0.87 \\
\hline Ruminating & 461.3 & 451.9 & 521.2 & 493.8 & 27.9 & 0.05 & 0.12 & 0.55 \\
\hline $\mathrm{TC}^{4}$ & 750.6 & 730.2 & 753.2 & 735.1 & 51.3 & 0.90 & 0.57 & 0.97 \\
\hline \multicolumn{9}{|l|}{ Min/kg DM } \\
\hline Eating & 10.8 & 9.27 & 9.7 & 9.5 & 1.0 & 0.57 & 0.43 & 0.40 \\
\hline Ruminating & 19.7 & 17.0 & 19.1 & 17.5 & 1.2 & 0.95 & 0.09 & 0.55 \\
\hline $\mathrm{TC}^{4}$ & 30.2 & 26.2 & 28.7 & 27.2 & 1.6 & 0.76 & 0.06 & 0.19 \\
\hline \multicolumn{9}{|l|}{$\mathrm{Min} / \mathrm{Kg} \mathrm{NDF}$} \\
\hline Eating & 39.8 & 30.5 & 32.49 & 29.40 & 3.89 & 0.22 & 0.12 & 0.35 \\
\hline Ruminating & 71.4 & 56.3 & 63.08 & 54.85 & 3.92 & 0.12 & 0.01 & 0.22 \\
\hline $\mathrm{TC}^{4}$ & 110.6 & 86.0 & 96.28 & 84.03 & 6.13 & 0.08 & $<0.01$ & 0.14 \\
\hline \multicolumn{9}{|l|}{ Bites/d } \\
\hline Eating & 4202 & 4580 & 5261 & 5452 & 1266 & 0.27 & 0.71 & 0.91 \\
\hline Ruminating & 29,736 & 27,238 & 29,691 & 27,015 & 1953 & 0.93 & 0.18 & 0.95 \\
\hline \multicolumn{9}{|l|}{ Bites/ kg DM } \\
\hline Eating & 172.47 & 166.6 & 203.90 & 199.02 & 45 & 0.31 & 0.84 & 0.98 \\
\hline Ruminating & 1170 & 981.7 & 1141 & 991.7 & 73.0 & 0.87 & 0.04 & 0.73 \\
\hline \multicolumn{9}{|l|}{ Bites/kg NDF } \\
\hline Eating & 613.4 & 553.2 & 682.8 & 613.6 & 158.5 & 0.52 & 0.48 & 0.96 \\
\hline Ruminating & 4243 & 3225 & 3817 & 3071 & 261.7 & 0.18 & $<0.01$ & 0.49 \\
\hline
\end{tabular}

${ }^{1} \mathrm{LGNH}=$ TMR with long corn silage, no cottonseed hulls, LGH = TMR with long corn silage and cottonseed hulls, SHNH = TMR with short corn silage and no cottonseed hulls, and SHH = TMR with short corn silage with cotton seed hulls.

${ }^{2} \mathrm{FPL} \times \mathrm{FS}$ interaction.

${ }^{3} \mathrm{NDFI}=$ Neutral detergent fiber intake.

${ }^{4} \mathrm{TC}=$ Total chewing activity (minutes eating + minutes ruminating). 
tion it was clear that many of the coarse high-fiber particles (stover and cob) of the corn silage were not consumed. Similarly, ort NDF content was significantly higher when long forage was fed (Table 5). Based on the observed interaction, sorting was greatest in cows consuming LGNH and was likely a result of this ration having the longest particle size. Rumination is correlated with NDF (Soita et al., 2000) and upon adjusting for NDFI, decreasing FPL resulted in a numerical decrease in ruminating time and total number of bites. Consequently, these results suggest that NDF may be more effective in stimulating chewing activity in long forage particles.

Although total time spent chewing was not different across treatments, the inclusion of $\mathrm{CSH}$ tended $(P<$ 0.1 ) to decrease TC per kilogram DMI (Table 6). In addition, time spent ruminating and number of ruminating bites per kilogram NDFI was significantly lower for diets containing CSH. The results of this study are similar to others that suggest chewing activity is reduced when NFFS are used to substitute for forage fiber (Clark and Armentano, 1997; Mooney and Allen, 1997; Allen and Grant, 2000). As previously mentioned, the inclusion of CSH also resulted in less material being retained on the sieve measuring 19.0 $\mathrm{mm}$ of the PSPS and was paired with lower chewing activities per unit of DM and NDFI intake and suggests that increasing the proportion of particles $>19.0$ $\mathrm{mm}$ is a primary factor affecting chewing activity.

\section{Apparent Nutrient Digestibilities, Rumen Fill, and Particle Size}

Apparent total-tract digestibility of diets are presented in Table 7. Dry matter digestibility tended ( $P$ $<0.1)$ to be higher for diets containing longer forage particles but was not affected by CSH inclusion. Apparent digestibility of $\mathrm{EE}$ was significantly higher for diets of longer silage particle size. These results are in contrast to other studies (Sudweeks et al., 1979; Schwab et al., 2002) that observed that increasing corn silage particle size did not affect EE digestibility. Increased EE digestibility was likely a result of the higher EE concentrations found in these diets. Although we have no explanation of why concentration of ration $\mathrm{EE}$ was higher in longer diets, these results are congruent with Palmquist and Conrad (1978) who reported that modest increases in fat would result in increased fat digestibility without reducing digestibility of other nutrients.

Digestibility of TNC was significantly lower while digestibility of NDF tended $(P<0.1)$ to be higher for diets containing $\mathrm{CSH}$, and these diets were consumed in greatest amounts. This effect is consistent with studies in which increasing level of intake reduced starch digestion, presumably a result of increased passage rate (NRC, 2001). Although it is generally believed that digestion of starch inhibits that of fiber through the reduction in rumen $\mathrm{pH}$ (Grant, 1994), this effect was not observed, as $\mathrm{pH}$ was higher (Table 8), presumably through increased chewing activity. These results support the idea that effects of rumen $\mathrm{pH}$ are sometimes overestimated and that depressed activity of cellulolytic microbes is not entirely a result of low $\mathrm{pH}$ but may also be inhibited by increased starch fermentation and substrate competition (Van Soest, 1994).

Rumen fill was not affected by FPL and is consistent with other studies examining this effect (Schwab et al., 2002; Table 7). Similar to DMI and NDFI, the inclusion of CSH resulted in greatest amounts of ruminal DM and NDF. Greater rumen fill was likely due to a greater consumption of NDF.

Feed, digesta, and fecal particle size data are presented in Table 9. Based on wet-sieving results, geometric mean length of both feed and digesta was significantly reduced when feeding $\mathrm{SH}$ corn silage, but these differences were not observed in the feces. For diets containing CSH more material was greater than $1.18 \mathrm{~mm}$ in both feed and digesta, but these differences were not observed in fecal samples. Although it has been speculated that particles $>1.18 \mathrm{~mm}$ must be reduced through chewing activity in order to escape from the rumen, diets with a greater proportion of DM $>1.18$ $\mathrm{mm}$ were paired with lowest chewing activity per unit of DM or NDF intake. This observation further supports the suggestion that the amount of $\mathrm{DM}>8 \mathrm{~mm}$ on the PSPS is a primary factor affecting chewing activity.

\section{Rumen Fermentation}

Rumen $\mathrm{pH}$, ammonia, and VFA concentration data are presented in Table 8 , and rumen $\mathrm{pH}$ is illustrated in Figure 1. Total VFA concentration was not affected by either FPL or inclusion of CSH, which is similar to other studies evaluating effects of corn silage particle length (Stockdale and Beavis, 1994; Bal et al., 2000; Schwab et al., 2002) or inclusion of CSH (Brown et al., 1977). In addition the concentration of acetate and propionate was unaffected by treatment, but the inclusion of CSH tended $(P<0.1)$ to result in a higher concentration of propionate and significantly increased the concentration of isobutyrate. Rumen ammonia concentrations were highest for cows fed diets containing CSH. Concentrations of VFA and ammonia were higher on diets containing $\mathrm{CSH}$ and likely a func- 
Table 7. Effects of forage particle length (FPL) and fiber source (FS) on nutrient digestibility, rumen fill, and liquid passage rate on dairy cows in early lactation.

\begin{tabular}{|c|c|c|c|c|c|c|c|c|}
\hline & \multicolumn{4}{|c|}{ Treatment $^{1}$} & \multirow[b]{2}{*}{ SEM } & \multicolumn{3}{|c|}{ Contrast } \\
\hline & LGNH & LGH & SHNH & SHH & & FPL & FS & $\mathrm{I}^{2}$ \\
\hline \multicolumn{9}{|l|}{ Digestibility } \\
\hline DM, \% & 67.0 & 66.7 & 64.0 & 63.8 & 1.03 & 0.06 & 0.74 & 0.96 \\
\hline $\mathrm{CP}, \%$ & 58.9 & 56.5 & 53.7 & 62.1 & 2.75 & 0.97 & 0.23 & 0.14 \\
\hline NDF, \% & 49.7 & 50.0 & 45.6 & 49.0 & 1.40 & 0.19 & 0.10 & 0.42 \\
\hline $\mathrm{ADF}, \%$ & 48.0 & 39.4 & 44.8 & 38.7 & 4.83 & 0.59 & 0.14 & 0.72 \\
\hline TNC, $\%^{3}$ & 70.2 & 62.2 & 66.4 & 61.5 & 2.82 & 0.30 & 0.04 & 0.46 \\
\hline $\mathrm{EE}, \%$ & 89.8 & 90.1 & 88.5 & 86.3 & 1.32 & 0.03 & 0.17 & 0.22 \\
\hline OM, \% & 67.5 & 67.2 & 66.6 & 65.9 & 1.6 & 0.45 & 0.76 & 0.90 \\
\hline NFC, $\% 4$ & 83.5 & 81.7 & 82.3 & 80.4 & 1.1 & 0.37 & 0.15 & 0.95 \\
\hline TDN, $\%{ }^{5}$ & 69.0 & 69.3 & 66.5 & 65.7 & 0.89 & 0.03 & 0.70 & 0.62 \\
\hline $\mathrm{NE}_{\mathrm{L}}, \mathrm{Mcal} / \mathrm{kg}^{6}$ & 1.67 & 1.67 & 1.59 & 1.58 & 0.03 & 0.05 & 0.97 & 0.91 \\
\hline \multicolumn{9}{|l|}{ Rumen fill $^{7}$} \\
\hline $\begin{array}{l}\text { Wet weight, kg } \\
\text { DM }\end{array}$ & 85.3 & 83.9 & 86.4 & 96.6 & 7.34 & 0.16 & 0.17 & 0.23 \\
\hline $\begin{array}{c}\text { Dill, } \\
\%\end{array}$ & 16.8 & 18.5 & 16.9 & 19.3 & 0.39 & 0.20 & $<0.01$ & 0.40 \\
\hline $\mathrm{kg}$ & 14.2 & 15.7 & 14.7 & 18.4 & 1.34 & 0.11 & 0.04 & 0.23 \\
\hline \multicolumn{9}{|l|}{$\mathrm{NDF}$, } \\
\hline$\%$ & 59.5 & 60.6 & 61.8 & 61.9 & 1.02 & 0.13 & 0.55 & 0.65 \\
\hline $\mathrm{kg}$ & 8.4 & 9.6 & 9.1 & 11.4 & 0.84 & 0.06 & 0.04 & 0.33 \\
\hline Liquid passage rate, $\% / \mathrm{h}$ & 12.5 & 13.6 & 12.1 & 11.8 & 0.67 & 0.01 & 0.40 & 0.05 \\
\hline
\end{tabular}

${ }^{1} \mathrm{LGNH}=$ TMR with long corn silage, no cottonseed hulls, LGH = TMR with long corn silage and cottonseed hulls, SHNH = TMR with short corn silage and no cottonseed hulls, and SHH = TMR with short corn silage with cottonseed hulls.

${ }^{2} \mathrm{FPL} \times \mathrm{FS}$ interaction.

${ }^{3} \mathrm{TNC}=$ Total nonstructural carbohydrate

${ }^{4} \mathrm{NFC}=$ Nonfiber carbohydrate calculated by difference.

${ }^{5} \mathrm{TDN}(\%)=\mathrm{tdNFC}+\mathrm{tdCP}+(\mathrm{tdEE} \times 2.25)+\mathrm{tdNDF}$.

${ }^{6} \mathrm{NE}_{\mathrm{Lp}}(\mathrm{Mcal} / \mathrm{kg})=$ Net energy of lactation at production levels, as described by NRC, $(2001)=0.703 \times$ $\mathrm{ME}_{\mathrm{p}}(\mathrm{Mcal} / \mathrm{kg})$.

${ }^{7}$ Manual empty.

tion of higher DMI and microbial activity (Maeng et al., 1997), but these differences were small and likely of limited biological significance. Finally, we cannot completely attribute effects to the sole replacement of fiber from $\mathrm{CSH}$ for corn silage, as diets containing CSH also contained more soybean meal and less wheat middlings and distillers grains. These differences would result in CSH diets containing NDF of NFFS

Table 8. Effects of forage particle length (FPL) and fiber source (FS) on ruminal concentration of VFA, ammonia $\left(\mathrm{NH}_{3} \mathrm{~N}\right)$, and blood concentration of NEFA on cows in early lactation.

\begin{tabular}{|c|c|c|c|c|c|c|c|c|}
\hline & \multicolumn{4}{|c|}{ Treatment $^{1}$} & \multirow[b]{2}{*}{ SEM } & \multicolumn{3}{|c|}{ Contrast } \\
\hline & LGNH & LGH & SHNH & $\mathrm{SHH}$ & & FPL & FS & $\mathrm{I}^{2}$ \\
\hline Rumen pH & 6.24 & 6.17 & 6.24 & 6.16 & 0.09 & 0.98 & 0.05 & 0.88 \\
\hline Total VFA (mM/L) & 99.3 & 106.2 & 98.8 & 103.7 & 4.7 & 0.73 & 0.18 & 0.82 \\
\hline \multicolumn{9}{|l|}{ VFA (mM/L) } \\
\hline Acetate & 60.1 & 64.8 & 60.8 & 63.0 & 2.8 & 0.84 & 0.20 & 0.64 \\
\hline Propionate & 21.7 & 22.9 & 20.2 & 22.6 & 1.3 & 0.43 & 0.10 & 0.58 \\
\hline Isobutyrate & 0.84 & 0.92 & 0.76 & 0.86 & 0.06 & 0.11 & 0.03 & 0.90 \\
\hline Butyrate & 12.4 & 13.1 & 12.7 & 12.8 & 0.63 & 0.96 & 0.47 & 0.53 \\
\hline Isovalerate & 2.11 & 2.21 & 2.19 & 2.24 & 0.18 & 0.46 & 0.32 & 0.99 \\
\hline Valerate & 2.29 & 2.30 & 2.24 & 2.24 & 0.07 & 0.41 & 0.92 & 0.96 \\
\hline $\mathrm{NH}_{3} \mathrm{~N}(\mathrm{mg} / \mathrm{dl})$ & 9.06 & 11.9 & 8.24 & 11.0 & 0.65 & 0.12 & $<0.01$ & 0.91 \\
\hline NEFA, $\mu \mathrm{eq} / \mathrm{L}$ & 85.3 & 93.1 & 95.7 & 110.0 & 11.9 & 0.33 & 0.36 & 0.81 \\
\hline
\end{tabular}

${ }^{1} \mathrm{LGNH}=\mathrm{TMR}$ with long corn silage, no cottonseed hulls, $\mathrm{LGH}=\mathrm{TMR}$ with long corn silage and cottonseed hulls, SHNH = TMR with short corn silage and no cottonseed hulls, and SHH = TMR with short corn silage with cottonseed hulls.

${ }^{2} \mathrm{FPL} \times \mathrm{FS}$ interaction. 
Table 9. The effect of forage particle length (FPL) and fiber source (FS) on the particle length of feed, digesta, and feces of cows in early lactation.

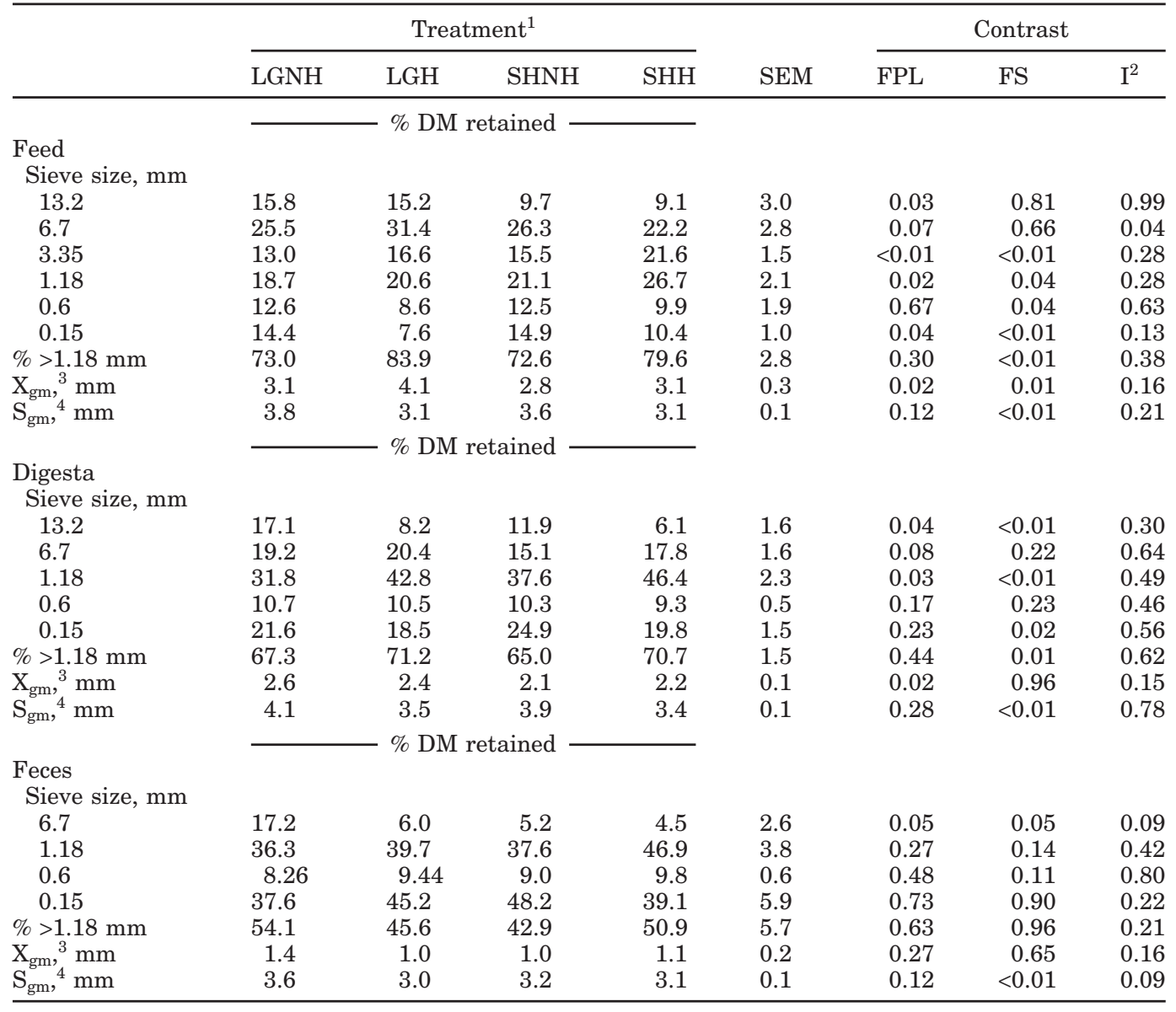

${ }^{1} \mathrm{LGNH}=\mathrm{TMR}$ with long corn silage, no cottonseed hulls, $\mathrm{LGH}=\mathrm{TMR}$ with long corn silage and cottonseed hulls, SHNH = TMR with short corn silage and no cottonseed hulls, and SHH = TMR with short corn silage with cottonseed hulls.

${ }^{2} \mathrm{FPL} \times \mathrm{FS}$ interaction.

${ }^{3} \mathrm{X}_{\mathrm{gm}}=$ Geometric mean length as calculated by the ASAE (S424), 2001.

${ }^{4} \mathrm{~S}_{\mathrm{gm}}=$ Geometric standard deviation as calculated by ASAE (S424), 2001.

origin that is more extensively degraded in the rumen (Firkins, 1997).

\section{Milk Production and Composition}

Milk production and composition data are presented in Table 10. Milk yield and 3.5\% FCM were similar across diets, averaging 48.5 and $48.1 \mathrm{~kg}$, respectively. These results agree with other studies where feeding corn silage of different physical form (Clark and Armentano, 1999; Schwab et al., 2002) or inclusion of CSH (Harris et al., 1983; Akinyode et al., 2000) did not affect milk production. Both percent and yield of milk protein were significantly higher for cows consuming shorter particle size. Increasing milk protein with decreasing corn silage particle size has been observed in other studies and is believed to be a result of increased starch digestibility (Clark and Armentano, 1999), as milk protein is positively correlated with dietary energy (Grieve et al., 1986). This explanation is further supported by observed effects of body weight gain.

Milk fat depression due to low ruminal $\mathrm{pH}$ and $\mathrm{A}: \mathrm{P}$ ratio was expected from cows consuming shorter forage and diets of shorter particle size as observed by Grant et al. (1990) and Fischer et al. (1994). In the present study, although percent milk fat tended $(P<0.1)$ to decrease with forage particle size, differences in rumen $\mathrm{pH}$ were small, indicating all diets were adequate in effective fiber. Lower observed milk fat percent was likely due to differences in milk yield and only tended $(P<0.1)$ to be different across treatments. The use of milk fat as a measure of fiber effectiveness has been 


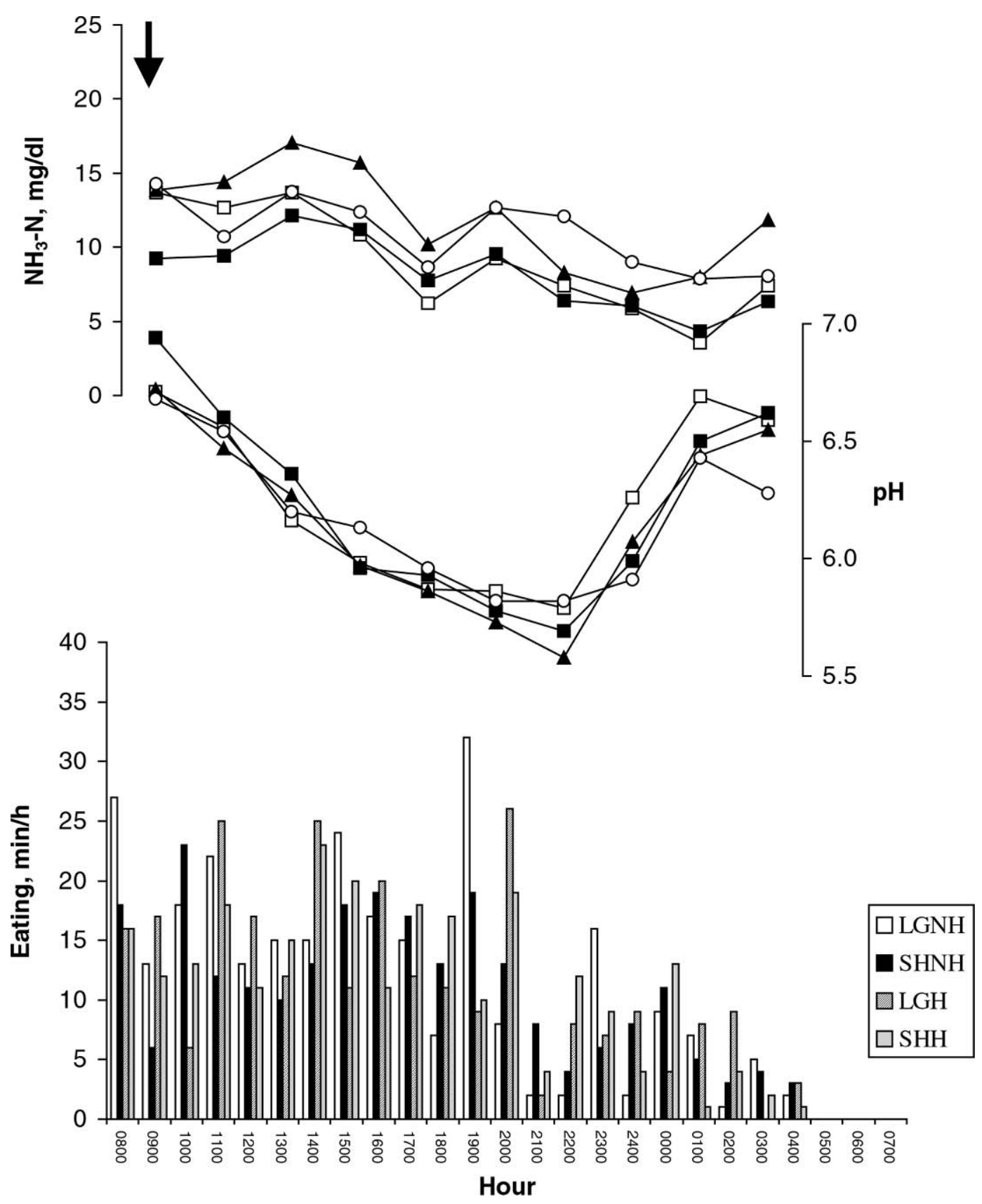

Figure 1. Daily rumen $\mathrm{pH}$ and $\mathrm{NH}_{3}-\mathrm{N}$ concentration and eating pattern in $\mathrm{min} / \mathrm{h}$ for a 24 -h period for dairy cows LGNH ( $\square$ ), $\mathrm{SHNH}$ $(\square)$, LGH ( $\mathbf{\Delta})$ or $\mathrm{SHH}(\mathrm{O})$. Arrow indicates feeding time.

questioned, especially for cows in early lactation, which are less responsive to dietary changes (Allen, 1997). The lack of response of milk fat to reduced particle size may also be due to the fact that rations met NRC (2001) requirements, and as suggested, it is more likely to see depression of milk fat when NDF is below minimum requirements (Beauchemin et al., 1997).

\section{Rumen Fermentation and Effective Fiber}

Dairy cattle require fiber in coarse physical form, which is effective in maintaining proper rumen health and function. Commonly, two methods are used to measure the effective fiber portion of dairy rations. Effective $\mathrm{NDF}$ is defined as the total ability of a feed to maintain 
Table 10. Effects of forage particle length (FPL) and fiber source (FS) on milk production and composition on cows in early lactation.

\begin{tabular}{|c|c|c|c|c|c|c|c|c|}
\hline & \multicolumn{4}{|c|}{ Treatment $^{1}$} & \multirow[b]{2}{*}{ SEM } & \multicolumn{3}{|c|}{ Contrast } \\
\hline & LGNH & LGH & SHNH & SHH & & FPL & FS & $\mathrm{I}^{2}$ \\
\hline Milk yield & 47.5 & 48.5 & 49.3 & 48.7 & 1.2 & 0.25 & 0.23 & 0.38 \\
\hline $3.5 \% \mathrm{FCM}$ & 48.3 & 48.2 & 47.7 & 48.3 & 1.0 & 0.67 & 0.62 & 0.34 \\
\hline Fat \% & 3.61 & 3.49 & 3.44 & 3.48 & 0.09 & 0.08 & 0.55 & 0.50 \\
\hline Fat, kg/d & 1.71 & 1.68 & 1.66 & 1.69 & 0.04 & 0.29 & 0.97 & 0.14 \\
\hline Protein \% & 2.63 & 2.64 & 2.65 & 2.68 & 0.04 & 0.04 & 0.24 & 0.93 \\
\hline Protein, kg/d & 1.24 & 1.27 & 1.27 & 1.30 & 0.03 & 0.03 & 0.08 & 0.88 \\
\hline MUN, ${ }^{3} \mathrm{mg} / \mathrm{dl}$ & 1166 & 1375 & 1125 & 1335 & 50.0 & 0.30 & $<0.01$ & 0.99 \\
\hline
\end{tabular}

${ }^{1} \mathrm{LGNH}=\mathrm{TMR}$ with long corn silage, no cottonseed hulls, LGH = TMR with long corn silage and cottonseed hulls, $\mathrm{SHNH}=$ TMR with short corn silage and no cottonseed hulls, and SHH = TMR with short corn silage with cottonseed hulls.

${ }^{2} \mathrm{FPL} \times \mathrm{FS}$ interaction.

${ }^{3}$ Milk urea nitrogen.

normal milk fat levels (Armentano and Pereira, 1997). Second, peNDF is defined as the physical properties of fiber that stimulates chewing activity and is measured by determining the proportion of NDF retained on a 1.18-mm sieve (Mertens, 1997).

The animal response used to measure peNDF is TC expressed as minutes per kilogram of NDFI. As particle size of rations increase the peNDF content is believed to also increase, resulting in elevated TC, salivary buffer secretion, and ruminal $\mathrm{pH}$ (Mertens, 1997). In the present study, even though reducing particle size of corn silage tended $(P<0.1)$ to reduce chewing activity, effects on rumen $\mathrm{pH}$ were not observed. Results of this study are consistent with others in which changes in physical structure of corn silage did not result in differences in ruminal pH (Stockdale and Beavis, 1994; Bal et al., 2000; Schwab et al., 2002) and suggest that the effective fiber value of corn silage is not necessarily affected by theoretical chop length and may depend upon degree of chopping or particle size distribution. In contrast, $\mathrm{CSH}$ significantly reduced both $\mathrm{TC}$ and rumen $\mathrm{pH}$; however, severe reductions in rumen $\mathrm{pH}$ were not observed (Figure 1). These results are similar to a number of other studies in which inclusion of NFFS reduced TC, but mean rumen $\mathrm{pH}$ was not observed to be below 6.0 (Allen and Grant, 2000). Recently, Yang et al. (2001) reported a lack of direct effect of peNDF on $\mathrm{pH}$ and suggested that measuring physical characteristics alone cannot be used to predict ruminal acidosis. Furthermore, the changes in daily saliva production and rumen $\mathrm{pH}$ from changes in TC have been overestimated as changes in total saliva production are small, because resting saliva secretion will also increase (Yang et al., 2001).

Thus, it seems likely that forage physical characteristics may have a smaller influence on rumen $\mathrm{pH}$ and fermentation than originally believed when rations meet NRC (2001) requirements. In comparison, characteristics, such as level of TNC in the ration, may have larger effects on $\mathrm{pH}$, and management of ration NSC level may be more useful in identifying rations resulting in large fluctuations of rumen $\mathrm{pH}$ or causing either clinical or subclinical acidosis. Furthermore, this study suggests that the proportion of NDF $\geq 1.18 \mathrm{~mm}$ does not differ in corn silage-based rations of different cut length and, as a result, is a poor measurement of effective fiber. More specifically, accounting for larger particles in the ration may result in a more accurate estimate in the ability of the ration to stimulate TC and sorting tendency.

\section{CONCLUSIONS}

Reducing particle size of corn silage did not significantly affect chewing activity, DMI, rumen $\mathrm{pH}$, apparent digestion of TNC and fiber, or milk production in early lactation. Although physical effectiveness of corn silage was not affected, results suggest that increasing particle size of corn silage may result in an increased sorting of the TMR. Substitution of approximately 8\% CSH for corn silage fiber reduced TMR particle size, decreasing TC per unit of NDFI, but increased DMI. Reduction in TC due to the incorporation of CSH merely resulted in small effects on rumen $\mathrm{pH}$ that did not affect milk production or percent fat and protein. Finally, results of this study are interpreted to indicate that peNDF, as measured by the PSPS, is a poor predictor of TC and rumen $\mathrm{pH}$, but measurement of particle size using the PSPS may be useful in understanding factors affecting feeding behavior.

\section{ACKNOWLEDGMENTS}

This research was supported in part by USDA grant no. 2000-34281-9764 and was a component of NC-119, 
Dairy Herd Management Strategies for Improving Decision Making and Profitability. The authors would also like to acknowledge financial support of Agway Ag Products-Keystone. The assistance with assays and sample collection of M. Long is much appreciated. Our appreciation to students T. Ross, A. Hess, K. Harvatine, N. Saloman, and S. Rodriguez, H. Lehman, and T. Haltman for feed preparation, sample collection, and analysis.

\section{REFERENCES}

Allen, M. S. 1997. Relationships between fermentation acid production in the rumen and the rumen and the requirement for physically effective fiber. J. Dairy Sci. 80:1447-1462.

Allen, D. M., and R. J. Grant. 2000. Interactions between forage and wet corn gluten feed as sources of fiber in diets for lactating dairy cattle. J. Dairy Sci. 83:322-331.

AOAC. 1990. Official Methods of Analysis. 15th ed. Assoc. of Official Analytical Chemists, Arlington, VA.

Armentano, L., and M. Pereira. 1997. Measuring the effectiveness of fiber by animal response trials. J. Dairy Sci. 80:1416-1425.

ASAE. 2001. S424. Method of determining and expressing particle size of chopped forage materials by sieving. In Standards Am. Soc. Agric. Eng., St. Joseph, MI.

Akinyode, A. M., M. B. Hall, C. R. Staples, H. H. Head, and W. E. Kunkle. 2000. Effects of cottonseed hulls in the diets of dairy cows. J. Dairy Sci. 83 (Suppl. 1):296. (Abstr.)

Bal, M. A., R. D. Shaver, A. G. Jirovec, K. J. Shinners, and J. G. Coors. 2000. Crop processing and chop length of corn silage: Effects on intake, digestion, and milk production by dairy cows. J. Dairy Sci. 83:1264-1273.

Beauchemin, K. A., and L. M. Rode. 1997. Minimum versus optimum concentrations of fiber in dairy cows diets based on barley silage and concentrates of barley and corn. J. Dairy Sci. 80:1629-1639.

Bhatti, A., and J. L. Firkins. 1995. Kinetics of hydration and functional specific gravity of fibrous feed by products. J. Anim. Sci. 73:1449-1458.

Broderick, G. A. and J. H. Kang. 1980. Automated simultaneous determination of ammonia and total amino acids in ruminal fluid and in vitro media. J. Dairy Sci. 63:64-75.

Brown, W. H., F. M. Whiting, B. S. Daboll, R. J. Turner, and J. D. Schuh. 1977. Pelleted and nonpelleted cottonseed hulls for lactating dairy cows. J. Dairy Sci. 60:919-923.

Clark, P. W., and L. E. Armentano. 1997. Influence of particle size on the effectiveness of beet pulp fiber. J. Dairy Sci. 80:898-904.

Clark, P. W., and L. E. Armentano. 1999. Influence of particle size on the effectiveness of fiber in corn silage. J. Dairy Sci. 82:581-588.

De Boever, J. L., D. L. Brabander, and J. M. Vanacker. 1993. Evaluation of physical structure. 2. Maize Silage. J. Dairy Sci. 76:1624-1634.

Firkins, J. L. 1997. Effects of feeding nonforage fiber sources on site of fiber digestion. J. Dairy Sci. 80:1426-1437.

Fischer, J. M., J. G. Buchanan-Smith, C. Campbell, D. G. Grieve, and O. B. Allen. 1994. Effects of forage particle size and long hay for cows fed total mixed rations based on alfalfa and corn. J. Dairy Sci. 77:217-229.

Grant, R. J., V. F. Colenbrander, and D. R. Mertens. 1990. Milk fat depression in dairy cows: role of silage particle size. J. Dairy. Sci. 73:1834-1842.

Grieve, D. G., S. Korver, Y. S. Rijpkema, G. Hof. 1986. Relationship between milk composition and some nutritional parameters in early lactation. 14:239-254.

Grovum, W. L., and V. J. Williams. 1973. Rate of passage of digesta in sheep. 3. Differential rates of passage of water and dry matter from the reticulo-rumen, abomasums, and caecum and proximal colon. Br. J. Nutr. 30:231-236.
Hall, M. B., and A. M. Akinyode. 2000. Cottonseed hulls:working with a novel fiber source. Pages 179-186 in Proc. 11th Ann. Florida Rumin. Nutr. Symp. Gainesville, FL.

Harris, B., H. H. Van Horn, K. E. Manookian, S. P. Marshall, M. J. Taylor, and C. J. Wilcox. 1983. Sugarcane silage, sodium hydroxide- and steam pressure- treated sugarcane bagasse, corn silage, cottonseed hulls, sodium bicarbonate, and aspergillis oryzae product in complete rations for lactating dairy cows. J. Dairy Sci. $66: 1474-1485$.

Hart, S. P., and C. E. Polan. 1984. Simultaneous extraction and determination of ytterbium and cobalt ethylenediamin-tetra-acetate complex in feces. J. Dairy Sci. 67:888-892.

Heinrichs, A. J., D. R. Buckmaster, and B. P. Lammers. 1999. Processing, mixing, and particle size reduction of forages for dairy cattle. J. Anim. Sci. 77:180-186.

Hsu, J. T., D. B. Faulkner, K. A. Garleb, R. A. Barclay, G. C. Fahey, and L. L. Berger. 1987. Evaluation of corn fiber, cottonseed hulls, oat hulls and soybean hulls as roughage sources for ruminants. J. Anim. Sci. 65:244-255.

Kononoff, P. J., A. J. Heinrichs, and D. A Buckmaster. 2003. Modification of the Penn State forage and TMR separator and the effects of moisture content on its measurements. In Press. J. Dairy Sci.

Lammers, B. P., D. R. Buckmaster, and A. J. Heinrichs. 1996. A simplified method for the analysis of particle sizes of forage and total mixed rations. J. Dairy Sci. 79:922-928.

Lykos, T., G. A. Varga, and D. P. Casper. 1997. Varying degradation rates of total nonstructural carbohydrates: effects on ruminal fermentation, blood metabolites, and milk production and composition in high producing Holstein cows. J. Dairy Sci. 80:33413355

Maeng, W. J., H. Park, and H. J. Kim. 1997. The role of carbohydrate supplementation in microbial protein synthesis in the rumen. Pages 107-119 in Rumen Microbes and Digestive Physiology in Ruminants. Onodera et al., ed. Japan Sci. Soc. Press, Tokyo/S. Karger, Basel.

Mertens, D. R. 1997. Creating a system for meeting the fiber requirements of dairy cattle. J. Dairy Sci. 80:1463-1482.

Methu, J. N., E. Owen, A. L. Abate, and J. C. Tanner. 2001. Botanical and nutritional composition of maize stover, intakes, and feed selection by dairy cattle. Livest. Prod. Sci. 71:87-96.

Mooney, C. S., and M. S. Allen. 1997. Physical effectiveness of the neutral detergent fiber of whole linted cottonseed relative to that of alfalfa silage at two lengths of cut. J. Dairy Sci. 80:2052-2061.

National Research Council. 2001. Nutrient Requirements of Dairy Cattle. 7th Rev. Edition. Natl. Acad. Sci., Washington, DC.

Palmquist, D. L., and H. R, Conrad. 1978. High fat rations for dairy cows. Effects on feed intake, milk and fat production and plasma metabolites. J. Dairy Sci. 61:890-901.

Poppi, D. P., R. E. Hendrickson, and D. J. Minson. 1985. The relative resistance to escape of leaf and stem particles from the rumen of cattle. J. Agric. Sci. 105:9-14.

Rutter, S. M., R. A. Champion, and P. D. Penning. 1997. An automatic system to record foraging behavior in free-ranging ruminants. Appl. Anim. Behav. Sci. 54:185-195.

SAS/STAT. User's Guide, Version 8.0. 1999. SAS Inst., Inc., Cary, NC.

Soita, H. W., D. A. Christensen, and J. J. McKinnon. 2000. Influence of particle size on the effectiveness of the fiber in barley silage. J. Dairy Sci. 83:2295-2300.

Stockdale C. R., and G. W. Beavis. 1994. Nutritional evaluation of whole plant maize ensiled at three chop lengths and fed to lactating dairy cattle. Aust. J. Exp. Agric. 34:709-716.

Schwab, E. C., R. D. Shaver, K. J. Shinners, J. G. Lauer, and J. G. Coors. 2002. Processing and chop length effects in brown-midrib corn silage on intake, digestion, and milk production by dairy cows. J. Dairy Sci. 85:613-623.

Smith, D. 1981. Removing and analyzing carbohydrates from plant tissue. Wisconsin Agric. Exp. Stn. Rep. No. R2107, Madison.

Sudweeks, E. M., L. O. Ely, and L. R. Sisk. 1979. Effect of particle size of corn silage on digestibility and rumen function. J. Dairy Sci. 62:292-296. 
Van Horn, H. H., B. Harris, M. J. Taylor, K. C. Bachman, and C. J. Wilcox. 1984. By-product feeds for lactating dairy cows:effects of cottonseed hulls, sunflower hulls, corrugated paper, peanut hulls, sugarcane bagasse and whole cottonseed with additives of fat, sodium bicarbonate and aspergillus oryzae product on milk production. J. Dairy Sci. 67:2922-2938.

Van Soest, P. J. 1994. Nutritional Ecology of the Ruminant, 2nd Edition. Comstock Publishing Associated, a division of Cornell University Press, Ithaca, NY.

Van Soest, P. J., J. B. Robertson, and B. A. Lewis. 1991. Symposium:Carbohydrate methodology, metabolism, and nutritional implications in dairy cattle. Methods for dietary fiber, neutral detergent fiber and non-starch polysaccharides in relation to animal nutrition. J. Dairy Sci. 74:3583-3597.
Weigand, E., U. Meyer, N. Guth. 1993. Intake, chewing activity and carbohydrate digestibility by lactating dairy cows fed maize silage with different physical structure. J. Anim. Physiol. Anim. Nutr. 69:120-132.

Weiss, W. P., H. R. Conrad, and N. R. St Pierre. 1992. A theoretically based model for predicting total digestible nutrient values of forages and concentrates. Anim. Feed Sci. Technol. 39:95-110.

Yang, C. M. J., and G. A. Varga. 1989. Effect of three concentrate feeding frequencies on rumen protozoa, rumen digesta kinetics, and milk yield in dairy cows. J. Dairy Sci. 72:950-957.

Yang, W. Z., K. A. Beauchemin, and L. A. Rode. 2001. Effects of grain processing, forage to concentrate ration, and forage particle size on rumen $\mathrm{pH}$ and digestion by dairy cattle. J. Dairy Sci. $84: 2203-2216$. 